\title{
PENGGUNAAN KIT IPA DALAM MENINGKATKAN HASIL BELAJAR IPA SISWA KELAS VI SD NEGERI 6 MATARAM
}

\author{
Endang P. Handayani1*, Syahrial Ayub² \\ ${ }^{1}$ SD Negeri 6 Mataram \\ ${ }^{2}$ Program Studi Pendidikan Fisika, Universitas Mataram \\ *Email: ndankhandayani@gmail.com
}

\begin{abstract}
This class action research aims to enhance the learning outcomes of the 6th graders of SD Negeri 6 Mataram in their science lesson by corporating Science KIT in teaching and learning activities inside the classroom. The research was conducted in 2 cycles, each of which included 4 different steps, namely, Planning, Action, Observation, and Reflection. After the research, it is shown that the average learning outcomes and classical completeness for the first cycle are 84,7 and $84 \%$, while the average learning outcomes and classical completeness for the second cycle are 88,4 and 94\% respectively. This thus shows an improvement in the students' learning outcomes, especially related to electrical and thermal energy. This conclusion is drawn after looking at the fact that $94 \%$ of the students score more than 75 in the test. This result is only obtained after the science KIT has already been applied in Science Lesson inside the classroom.
\end{abstract}

Keywords: Science KIT, Science Lesson, Students' Outcome

\section{PENDAHULUAN}

Berbagai usaha telah dilakukan pemerintah untuk meningkatkan mutu pendidikan dan pengajaran IPA di Sekolah Dasar. Namun mutu pendidikan IPA masih merupakan isu yang hangat dibicarakan diberbagai forum ilmiah, akibat masih rendah pemahaman konsep IPA siswa. Pemahaman konsep siswa pada mata pelajaran IPA, yang rata-rata kurang dari $67 \%$ dianggap masih rendah. Data ini menunjukkan bahwa kualitas pembelajaran IPA perlu ditingkatkan supaya pemahaman konsep IPA siswa meningkat.

Terdapat beberapa permasalahan yang ditemukan dalam pembelajaran IPA di SD, adalah: (1) Konsep-konsep IPA dapat ditransfer dari guru ke siswa. Asumsi ini menyebabkan guru terfokus untuk memberi pengetahuan sebanyak-banyaknya sesuai dengan target kurikulum. Guru akan merasa mengajar dengan baik bila daya capai kurikulum mencapai $100 \%$. Akan tetapi kenyataannya, guru sering kecewa karena daya serap dan ketuntasan belajar siswa masih rendah dibawah 67\%. (2) Pola pembelajaran IPA di SD sebagian besar masih berlangsung secara konvensional, sehingga pembelajaran berlangsung satu arah saja, yaitu guru memberi dan siswa menerima. Tampaknya, pembelajaran semacam ini cenderung hanya menghabiskan materi kurikulum daripada menanamkan konsep yang benar pada siswa. (3) Selama ini, guru IPA jarang menggali dan memberikan perhatian pada konsepsi awal siswa terhadap suatu konsep IPA. Hasil-hasil penelitian terdahulu (Santyasa, 1997) menunjukkan bahwa pengabaian terhadap gagasan-gagasan awal siswa telah menimbulkan kegagalan pada pembelajaran IPA. (4) Kegagalan siswa dalam memecahkan persoalan IPA diakibatkan oleh siswa yang tidak dapat melihat adanya keterkaitan antar konsep yang sudah dipelajari dengan konsep yang sedang dipelajari. Hal ini menunjukkan bahwa proses pembelajaran IPA yang dialami belum bermakna. Pembelajaran bermakna akan terjadi bila siswa melihat kaitan diantara konsep-konsep yang dipelajari (Dahar, 1989). Hamdanillah et al. (2017) juga menjelaskan bahwa untuk membentuk pembelajaran yang bermakna, guru perlu 
menggali pengetahuan awal dari siswa. Pengetahuan awal inilah yang akan membentuk pengetahuan baru pada materi yang diajarkan. Mengggali pengetahuna awal siswa dapat dilakukan dengan berbagai macam cara, salah satunya dengan memanfaatkan media pembelajaran yang ada. Tamami et al. (2017) juga menjelaskan pentingnya media pembelajaran dalam memfasilitasi siswa dalam menuangkan gagasan-gagasannya.

KIT IPA merupakan salah satu media yang dapat digunakan pada pembelajaran IPA di SD. Penggunaan Media KIT IPA selain meningkatkan kemampuan kognitif siswa dalam pembelajaran, juga sangat terkait dengan aspek afektif dan psikomotornya (Indayani, 2015). Hal inilah yang dirasakan masih kurang pada pembelajaran IPA di kelas VI SDN 6 Mataram. Pembelajaran IPA yang dilakukan pada kelas VI yaitu sampel penelitian ini sudah berorientasi pada proses tapi penulis rasakan belum optimal, karena belum menggunakan peralatan atau KIT yang relevan. Logikanya, jika anak langsung dihadapkan pada hal yang nyata secara teori akan memberikan hasil yang lebih baik dan berkesan dalam menemukan sebuah konsep daripada tanpa menggunakannya. Hal yang nyata tersebut juga dapat disebut sebagai pembelajaran yang kontekstual. Sebagaimana penelitian yang dilakukan oleh Oktaviani et al. (2017), penggunaan bahan ajar yang kontekstual dapat meningkatkan pemahaman siswa akan pelajaran yang diajarkan. Hal inilah yang penulis rasakan pada pembelajaran IPA di kelas VI SD Negeri 6 Mataram.

Berdasarkan

identifikasi permasalahan tersebut, tampaknya proses pembelajaran IPA di SD perlu dioptimalisasikan untuk meningkatkan pemahaman konsep IPA. Ada beberapa konsep yang harus dipahami siswa, yaitu pada materi yang berkaitan dengan konduktor dan isolator pada listrik dan juga pada hantaran/transfer panas pada benda padat, zat cair dan gas, serta hantaran/transfer panas secara radiasi. Proses optimalisasi diupayakan dengan menerapkan Kit IPA dalam kegiatan belajar mengajar di kelas.

Karena itu, berdasarkan dari uraian pada latar belakang yang dijelaskan di atas, rumusan masalah yang diajukan dalam penelitian ini antara lain adalah: Bagaimana meningkatkan hasil belajar IPA siswa di kelas VI SD Negeri 6 Mataram dengan menggunakan Kit IPA dalam pembelajaran?

\section{METODE PENELITIAN}

Penelitian ini menggunakan rancangan penelitian tindakan kelas. Ciri khas Penelitian Tindakan Kelas adalah adanya evaluasi yang diberikan setiap selesai satu siklus. PTK ini terdiri dari 2 siklus berbeda yang masih-masingnya memiliki 4 tahapan yaitu; 1) Perencanaan; 2) Tindakan; 3) Observasi; 4) Evaluasi dan Refleksi. Adapun tahapan-tahapan tiap siklus adalah sebagai berikut:

\section{Siklus I}

1. Tahap Perencanaan I

Kegiatan yang dilakukan pada tahap ini adalah :

a. mengkomunikasikan hasil studi awal tentang pembelajaran IPA dan hasil belajar siswa;

b. membuat skenario pembelajaran yang mencerminkan implementasi Kit IPA pada pembelajaran di kelas;

c. menyusun instrumen penelitian;

d. menyepakati indikator-indikator keberhasilan tindakan bersama guru dan peneliti;

2. Tahap Tindakan I

Pada tahap tindakan I, yang dilaksanakan adalah:

a. mengumpulkan data pengetahuan awal dan mengidentifikasi kesulitan 
kesulitan yang dihadapi guru dan siswa dalam pembelajaran IPA di kelas khususnya pada konsep energi listrik;

b. melaksanakan tahapan-tahapan pembelajaran;

c. mengklarifikasi kesulitan-kesulitan guru dalam pembelajaran IPA di kelas dan pengembangan konsep siswa dengan penggunaan Kit IPA.

3. Tahap Observasi/Evaluasi I

Pada tahap ini, dilakukan :

a. observasi proses dan pengaruh tindakan serta hambatanhambatannya dengan menggunakan pedoman observasi;

b. mengevaluasi pencapaian hasil belajar siswa dengan tes hasil belajar tentang pemahaman konsep energi.

4. Tahap Refleksi I

Refleksi dilakukan setiap selesai tindakan bersama-sama tim peneliti untuk mengkaji atau menganalisis temuantemuan dalam tindakan yang telah dilakukan. Hambatan dan kelemahan pelaksanaan tindakan perlu dicarikan alternatif pemecahannya sebagai masukan pada perencanaan tindakan berikutnya.

\section{Siklus II}

\section{Tahap Perencanaan II}

Kegiatan yang dilakukan pada tahap ini adalah :

a. membahas hambatan dan kelemahan pelaksanaan siklus I, sebagai masukan yang berarti bagi pelaksanaan siklus II

b. membuat skenario pembelajaran yang mencerminkan implementasi Kit IPA pada materi pembelajaran IPA selanjutnya

2. Tahap Tindakan II

Pada tahap tindakan II, yang dilaksanakan adalah: a. mengumpulkan data pengetahuan awal dan mengidentifikasi kesulitankesulitan yang dihadapi guru dalam pembelajaran IPA di kelas.

b. melaksanakan tahapan-tahapan pembelajaran

c. mengklarifikasi kesulitan kesulitan yang dihadapi guru dalam pembelajaran IPA di kelas dan pengembangan konsep siswa dengan menggunakan Kit IPA.

3. Tahap Observasi/Evaluasi II

Pada tahap ini, dilakukan :

a. observasi proses dan pengaruh tindakan serta hambatanhambatannya dengan menggunakan pedoman observasi

b. mengevaluasi pencapaian hasil belajar siswa dengan tes hasil belajar

4. Tahap Refleksi II

Refleksi dilakukan setiap selesai tindakan bersama-sama tim peneliti untuk mengkaji atau menganalisis temuantemuan dalam tindakan yang telah dilakukan.

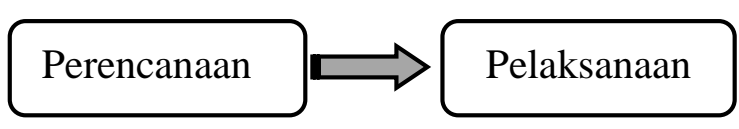

Siklus I

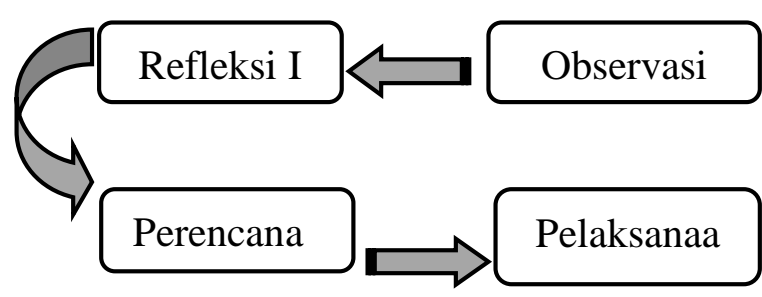

Siklus II

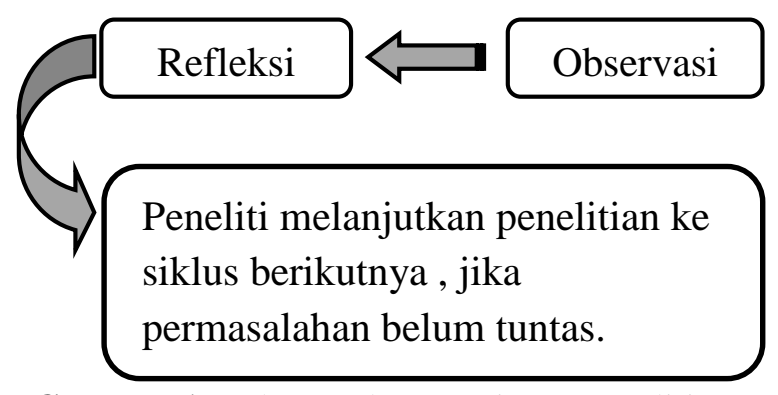

Gambar 1. Tahap-Tahap Kegiatan Penelitian Tindakan Kelas (Iskandar, 2009) 
Hambatan dan kelemahan pelaksanaan tindakan perlu dicarikan alternatif pemecahannya sebagai masukan pada perencanaan tindakan berikutnya. Adapun secara ringkas tahap-tahap kegiatan dalam penelitian tindakan kelas ini adalah:

\section{Indikator Keberhasilan}

Untuk menentukan banyaknya siklus yang harus dilakukan mengacu pada indikator keberhasilan Penelitian Tindakan Kelas., yakni siklus akan dianggap selesai bila:

1. $85 \%$ siswa kelas VI SD mencapai nilai $\mathrm{KKM} \geq 75$.

2. Menunjukkan adanya sikap ilmiah pada siswa dengan kategori baik.

\section{HASIL DAN PEMBAHASAN}

\section{Hasil Belajar IPA}

Berdasarkan hasil penelitian yang telah dilaksanakan, hasil belajar siswa dari siklus I dan siklus II dapat dipersentasikan melalui Gambar 1 dan 2 berikut.

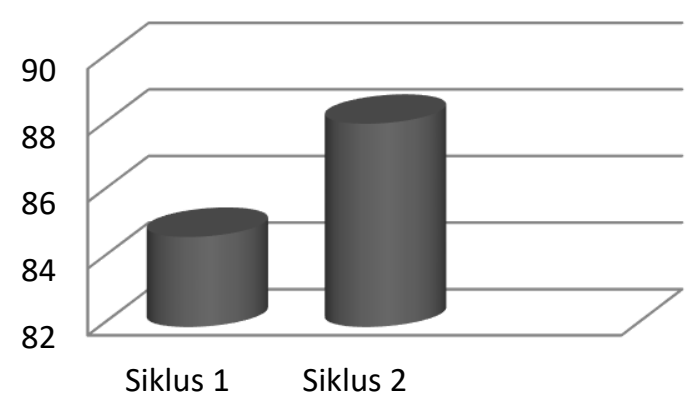

Gambar 2. Grafik Rata-Rata Kelas Siswa per siklus

Berdasarkan grafik tersebut menunjukkan bahwa, hasil belajar siswa pada siklus I diperoleh nilai rata-rata kelas sebesar 84.7 dengan ketuntasan klasikal sebesar $84 \%$, hal tersebut menunjukkan bahwa hasil belajar siswa belum mencapai indikator keberhasilan, yaitu jika ketuntasan klasikal yang memperoleh nilai $\geq 75$ kurang dari $85 \%$, sehingga penelitian dilanjutkan ke siklus II. Dan pada siklus II diperoleh nilai rata-rata kelas sebesar 88.4 dengan ketuntasan klasikal sebesar $94 \%$ hal tersebut menunjukkan adanya peningkatan.

Berdasarkan grafik tersebut menunjukkan bahwa, hasil belajar siswa pada siklus I diperoleh nilai rata-rata kelas sebesar 84.7 dengan ketuntasan klasikal sebesar $84 \%$, hal tersebut menunjukkan bahwa hasil belajar siswa belum mencapai indikator keberhasilan, yaitu jika ketuntasan klasikal yang memperoleh nilai $\geq 75$ kurang dari $85 \%$, sehingga penelitian dilanjutkan ke siklus II. Dan pada siklus II diperoleh nilai rata-rata kelas sebesar 88.4 dengan ketuntasan klasikal sebesar $94 \%$ hal tersebut menunjukkan adanya peningkatan.

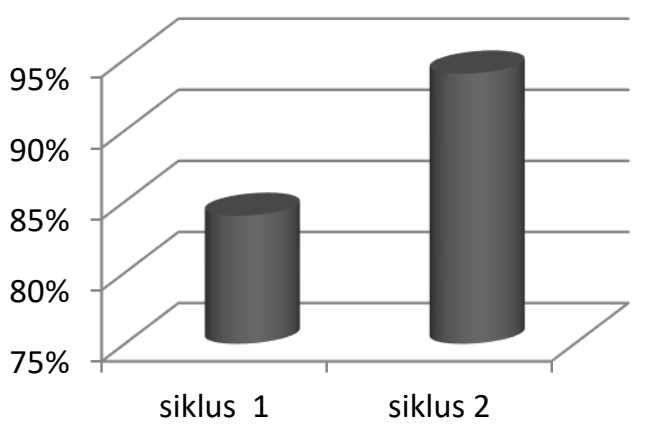

Gambar 3. Grafik ketuntasan klasikal hasil belajar siswa

\section{Siklus I}

Pada siklus I, masih terdapat kendala-kendala serta kekurangankekurangan selama proses pembelajaran berlangsung. Kendala-kendala yang dihadapi selama menerapkan model pembelajaran dengan Kit IPA yaitu kurang maksimalnya guru dalam mengelola kelas dikarenakan banyaknya jumlah siswa sehingga masih ada siswa yang kurang serius dan ribut selama proses pembelajaran berlangsung. Untuk mengatasi kendala tersebut maka guru berusaha mengelola kelas dan menerapkan model pembelajaran dengan Kit IPA dengan baik serta mencari alternatif-alternatif lain seperti meminta siswa yang ribut untuk mempresentasikan hasil diskusi kelompoknya di depan kelas, dan dengan memberi teguran pada siswa 
yang mengganggu jalannya proses pembelajaran berlangsung untuk mengantisipasi penggunaan waktu yang tidak efektif pada saat kegiatan belajar mengajar berlangsung.

Selain kendala-kendala yang telah disebutkan di atas, ternyata pada siklus I ini, ada beberapa siswa yang mendapat nilai jauh di bawah rata-rata. Hal tersebut disebabkan karena belum tergugahnya keinginan mereka untuk serius belajar dengan menggunakan Kit IPA. Dengan demikian, pada saat pelaksanaan penelitian pada siklus II nanti, peneliti harus memperhatikan faktor-faktor yang telah disebutkan di atas.

\section{Siklus II}

Pada siklus II, diperoleh nilai ratarata kelas sebesar 88,4 sedangkan ketuntasan klasikal diperoleh $94 \%$ siswa. Dengan demikian siklus dapat dihentikan karna telah mencapai indikator keberhasilan.

Melalui penggunaan Kit IPA dalam pembelajaran yang telah dilakukan dalam penelitian ini dapat memberi manfaat positif bagi siswa. Manfaat yang dapat diambil yaitu siswa tidak lagi merasa bosan saat pembelajaran berlangsung. Selain itu, siswa menjadi lebih aktif dan tidak merasa malu untuk bertanya baik pada guru ataupun teman sekelas. Pembelajaran dengan penggunaan Kit IPA merupakan model pembelajaran kelompok dimana terdapat seorang siswa yang lebih mampu berperan sebagai tutor sebaya yang bertugas membantu secara individual siswa lain yang kurang mampu dalam suatu kelompok. Dalam hal ini pendidik hanya sebagai fasilitator dan mediator dalam proses belajar mengajar. Pendidik cukup menciptakan kondisi lingkungan belajar yang kondusif bagi peserta didiknya. Pembelajaran kooperatif merupakan strategi pembelajaran yang mendorong siswa aktif menemukan sendiri pengetahuannya melalui keterampilan proses. Siswa belajar dalam kelompok kecil yang kemampuannya heterogen dalam menyelesaikan tugas kelompok, setiap anggota saling bekerja sama dan membantu dalam memahami suatu bahan ajar dan bahan diskusi. Selama kerja kelompok, tugas anggota kelompok adalah mencapai ketuntasan materi dan saling membantu teman sekelompok mencapai ketuntasan (Slavin, 1995).

Dengan mengintegrasikan Kit IPA dapat meningkatkan hasil belajar IPA siswa kelas VI SD Negeri 6 Mataram.

\section{Respon dan Observasi Aktivitas Siswa Terhadap Pembelajaran Kit IPA}

Berdasarkan hasil angket dan observasi siswa terhadap penggunaan Kit energi dalam pembelajaran memperlihatkan nilai yang sangat baik (konversi berdasarkan tabel 3.6). Data respon siswa terhadap penggunaan Kit IPA dapat diperoleh jumlah skor total angket adalah 1340 dengan persentase $84 \%$.

Hal ini menunjukkan bahwa siswa sangat tertarik dengan penggunaan Kit IPA dalam pembelajaran karena dapat membuat mereka senang dan termotivasi dalam belajar IPA yang pada akhirnya mampu meningkatkan hasil belajar mereka.

Pembelajaran dengan menggunakan Kit IPA, siswa langsung berhadapan dengan kondisi yang sebenarnya dan melakukan kegiatan untuk menemukan suatu konsep. Siswa yang menemukan masalah pembelajaran, siswa yang melakukan kegiatan (percobaan) untuk menjawab permasalahan dan pada akhirnya siswa juga yang menyimpulkan. Guru hanya sebagai fasilitator yang mampu menggiring siswa berada pada jalur yang benar.

Metode ini jelas disenangi oleh siswa karena siswa ditempatkan sebagai penentu dalam pembelajaran sehingga angket respon siswa terhadap pembelajaran dengan Kit IPA berada pada kategori sangat baik. 


\section{Sikap Ilmiah Siswa}

Sikap ilmiah yang diungkap pada penelitian ini antara lain rasa ingin tahu, kerjasama tim, pengambilan keputusan yang bertanggung jawab, bekerja keras dan mengkomunikasikan hasil kegiatan, Hasil penelitian memperlihatkan rata-rata skor observasi sikap ilmiah pada setiap siklus meningkat, yaitu 78,2 dan 94,4 dengan kategori sangat baik. Ini menunjukkan bahwa kemampuan ilmiah siswa meningkat juga. Bimbingan guru, motivasi dan respon anak yang sangat baik terhadap pembelajaran dengan Kit IPA menjadi sumbernya. Bila anak selalu dan terus menerus dilatih dengan perlakuan yang tepat pasti akan membawa perubahan yang baik pada diri siswa.

\section{Observasi Guru dalam Pembelajaran dengan Kit IPA}

Kualitas pembelajaran yang dilakukan oleh guru disetiap siklus meningkat, hal ini terlihat jelas pada ratarata skor observasi pembelajaran di setiap siklus yaitu 74 dan 80 .

Pada awal pembelajaran guru melakukan berbagai kegiatan untuk memotivasi siswa agar tertarik mengikuti pembelajaran yang akan dilakukan. Disamping termotivasi diharapkan siswa juga mampu menemukan permasalahan belajar sendiri. Jadi tidak diberikan oleh guru sehingga ini akan menambah keinginan siswa untuk mempelajarinya. Permasalahan yang muncul tidak langsung dijawab oleh guru, guru hanya meminta opini/hipotesa dari siswa. Jawaban-jawaban siswa ini tidak dibenarkan atau disalahkan, guru hanya menampung sambil memberi penghargaan pada siswa.

Selanjutnya guru mengajak siswa melakukan kegiatan untuk menjawab permasalahan tersebut. Kegiatan yang bisa dilakukan adalah percobaan, simulasi atau permainan, klasifikasi atau pengelompokan, memeriksa cara kerja alat teknis dan sebagainya. Pada penelitian guru sebagian besar guru melakukan kegiatan percobaan. Dari hasil pengamatan dan pengumpulan data serta diskusi dengan landasan teori yang baik diharapkan di akhir kegiatan inti ini siswa mampu menyimpulkan sendiri dan menemukan konsep pembelajarannya. Bila kesimpulan telah tercapai maka permasalahan yang ditemukan di awal pembelajaran terjawab. Siswa akan merasakan sendiri jawabannya salah atau benar, jadi bukan guru yang memberitahu.

Diakhir pembelajaran guru menjelaskan penerapan dari konsep yang baru ditemukan, bisa juga memberikan evaluasi dan pekerjaan rumah. Inilah langkah-langkah yang dilakukan guru.

\section{PENUTUP}

Berdasarkan hasil dan pembahasan yang telah dilakukan, maka dapat disimpulkan sebagai berikut:

1. Hasil belajar IPA siswa SD Negeri 6 Mataram meningkat dengan penggunaan kit IPA dalam proses pembelajaran di kelas.

2. Sintak pembelajaran yang direkomendasikan pada penelitian ini adalah menggali pengetahuan awal siswa (apersepsi), melakukan kegiatan dengan cooperatif learning sederhana sampai siswa menemukan kesimpulan, dan terakhir menjelaskan penerapan konsep dalam kehidupan sehari-hari.

Adapun saran-saran yang dapat diberikan adalah sebagai berikut:

1. Bagi guru SD diharapkan dapat menggunakan Kit IPA dalam mengajarkan setiap pokok bahasan dalam materi IPA untuk meningkatkan hasil belajarnya, apabila menemukan permasalahan yang sama yaitu rendahnya hasil belajar IPA. 
2. Bagi Sekolah diharapkan lebih mengembangkan sarana dan prasarana pembelajaran khususnya IPA agar dapat meningkatkan mutu lulusan yang berkualitas.

\section{REFERENSI}

Dahar, W.M. 1989. Teori-Teori Belajar. Jakarta: Erlangga.

Hamdanillah, N., Harjono, A., \& Susilawati. 2017. Pengaruh Model Pembelajaran Advance Organizer Menggunakan Video Pembelajaran Terhadap Hasil Belajar Fisika Peserta Didik Kelas XI. Jurnal Pendidikan Fisika dan Teknologi, 3(2), 119-127.

Indayani, L. (2015). Peningkatan Prestasi Belajar Peserta Didik Melalui Penggunaan Media KIT IPA di SMP Negeri 10 Probolinggo. Jurnal Kebijakan dan Pengembangan Pendidikan, 3(1).

Iskandar. 2009. Metodologi Penelitian Pendidikan dan Sosial (Kuantitatif dan Kualitatif). Jakarta: GP Press.

Oktaviani, W., Gunawan, \& Sutrio. 2017. Pengembangan Bahan Ajar Fisika Kontekstual Untuk Meningkatkan Penguasaan Konsep Siswa. Jurnal Pendidikan Fisika dan Teknologi, 3(1), 1-7.

Santyasa, 1997. Pembelajaran Modul dengan Metode Demontrasi dan Analogi Sebagai Strategi Pengubah Miskonsepsi Mahasiswa Jurusan Pendidikan MIPA. Laporan Penelitian. STKIP Singaraja.

Tamami, F., Rokhmat, J., \& Gunada, I. W. 2017. Pengaruh Pendekatan Berpikir Kausalitik Scaffolding Tipe 2a Modifikasi Berbantuan LKS Terhadap Kemampuan Pemecahan Masalah Optik Geometri dan Kreativitas Siswa Kelas XI SMAN 1 Mataram. Jurnal Pendidikan Fisika dan Teknologi, 3(1), 76-83.

Slavin, R.E. 1995. Cooperative Learning. London: Allyn and Bacon. 